\title{
Öğretmenlerin Etkileşimli Tahtaya Yönelik Tutumlarının Değerlendirilmesi: Peace With ICT Avrupa Birliği Proje Örneği
}

\section{Faruk AYATA*, Taner UÇKAN**, Hayati ÇAVUŞ ${ }^{* * *}$, Ebubekir SEYYARER ${ }^{* * * *}$}

Öz: Dünyamızdaki tüm ülkelerde olduğu gibi ülkemizdeki eğitim alanlarında da birçok gelişmeler yaşanmaktadır. Bu gelişmelerde etkileşimli tahtaların etkisi çoktur. Özellikle Endüstri 4.0 ve sonrasında eğitimde teknoloji kullanımının yanı sıra, örgün eğitim ortamlarında (sınıflarda) etkileşimli tahta kullanımı yaygınlaşmıştır. Bu çalışmanın amacı; İtalya, Slovenya, Romanya ve Türkiye'nin ortaklığıyla gerçekleştirilen "Peace With ICT” isimli Avrupa Birliği (AB) projesinin çıktılarını değerlendirilerek, ülkelerdeki ortak kuruluşlarda çalışan eğitmenlerin etkileşimli tahtaya yönelik tutumlarını ortaya koyan bir istatistiksel veri analizi çalışması yapmaktır. Ülkemizde etkileşimli tahta kullanımının yaygınlaşması FATİH (Fırsatları Artırma ve Teknolojiyi İyileştirme Hareketi) projesi ile hız kazanmıştır. Konu ile ilgili yapılan araştırmalarda/incelemelerde, öğretmenlerin eski alışkanlıkları nedeniyle dijital teknolojileri kullanmakta tereddüt ettikleri görülmektedir. Etkileşimli tahtalar, projeksiyon cihazı olarak ve öğrencilere verilen tabletler de oyun konsolu olarak görülmektedir. Bu durumun her anlamda israfa neden olmasından endişe duyulmaktadır.

Çalışmada İtalya'dan 45, Slovenya'dan 50, Romanya'dan 107 ve Türkiye'den 69 kişi olmak üzere toplam 271 eğitimciye 22 maddeden oluşan likert tipi bir ölçek uygulanmıştır. Verilerin analizinde parametrik testler kullanılmıştır. Etkileşimli tahta kullanımı ölçeğinin demografik değişkenlere göre farklılık gösterip göstermediğini test etmek için T-Testi ve Anova Analizinden yararlanılmıştır. Ülke ve Mesleki deneyim değişkenlerinin aralarındaki ilişkiyi anlamak üzere yapılan istatistiki analizler sonucunda, farkındalık eğitimi sonrasında 1-

*Öğr. Gör. Van Yüzüncü Y1l Üniversitesi Başkale Meslek Yüksek Okulu, Email:farukayata@yyu.edu.tr Orcid No: 00000003-2403-3192.

** Öğr. Gör. Van Yüzüncü Y1l Üniversitesi Başkale Meslek Yüksek Okulu, Email:taneruckan@yyu.edu.tr Orcid No:0000001-5385-6775.

${ }^{* * *}$ Doç. Dr. Van Yüzüncü Y1l Üniversitesi Eğitim Fakültesi, BÖTE Bölümü, Email:hayatiicavus@gmail.com Orcid No: 0000-0001-5602-5221.

**** Öğr. Gör. Van Yüzüncü Yı1 Üniversitesi Gevaş Meslek Yüksek Okulu, Email:eseyyarer@gmail.com Orcid No:0000002-8981-0266. 
5 yıllık mesleki deneyime sahip kişilerin etkileşimli tahtayı daha sık kullandığı ve ülke bazlı en iyi gelişmeyi de Türkiye'nin gösterdiği görülmektedir. Ayrıca uygulanan ölçek tüm ortak kuruluşlarda farkındalık eğitimi öncesi ön test, sonrasında ise son test olarak uygulanmıştır ve ülkeler arasındaki farklar belirlenmiştir. Farkındalık eğitimi öncesinde katılımcı ülkelerin etkileşimli tahtaya olan tutumları, Bilgi ve iletişim teknolojilerine ait bilgi birikimlerinin az olmasından kaynaklı, çekimser ve kararsız olarak görünse de eğitim sonrasında bu tutumun olumlu yönde geliştiği ve yapılan istatistiksel analizlerin sonucuna göre Etkileşimli tahtaya olan tutumları toplamda \%32.02 oranında gelişim gösterdiği görülmüştür. Benzer çalışmaların farklı ülkelerde de yapılması ve elde edilen sonuçların karşılaştırılarak daha anlamlı sonuçlara ulaşılması noktasında faydalı olacaktır.

Anahtar Kelimeler: Bilgi ve iletişim teknolojileri, Peace With ICT, Etkileşimli tahta, Tutum, Öğretmen.

\section{Evaluating of Teachers Attitudes Towards Interactive Boards: Peace With ICT European Union Project Example}

Abstract: As in all countries in our world, many developments are taking place in the fields of education in our country. Interactive boards have a great impact on these developments. In addition to the use of technology in education, especially in Industry 4.0 and later, the use of interactive boards in formal education environments (classrooms) has become widespread. The aim of this study is; İtalya, Slovenya, Romanya and performed with Türkiye's partnership with "Peace With ICT" is the European Union (EU) evaluated the outcomes of the project, employee trainers in public institutions in the country who put their attitudes towards interactive whiteboard is to make a statistical data analysis work. The widespread use of interactive boards in our country has gained momentum with the FATİH (Increasing Opportunities and Technology Improvement Movement) project. In researches / examinations on the subject, it is observed that teachers hesitate to use digital technologies due to their old habits. Interactive boards are seen as projection devices and tablets given to students as game consoles. This situation causes waste in every sense.

In the study 45 from Italy, 50 from Slovenia, 107 from Romania and as 69 from Turkey the survey was administered to a total of 271 educators a Likert-type scale consisting of 22 items. Paremetric tests were used to analyze the data. T-Test and Anova Analysis were used to test whether the scale of interactive board usage differs according to demographic variables. Country and as a result of statistical analysis conducted to understand the relationship between 
their professional experience variables, it is observed that after awareness training 1-5 years of professional experience with a person of the interactive whiteboard more frequently used and country-specific best development in Turkey's show. Additionally survey aplied was applied as a pre-test before the awareness training and as a post-test after the awareness training in all partner organizations, and the differences between countries were determined. According to the results of the statistical analysis conducted before and after the awareness training, it was seen that the participating countries showed a total improvement of $32.02 \%$. It will be useful to conduct similar studies in different countries and to achieve more meaningful results by comparing the results obtained.

Keywords: Information and communication technologies, Peace With ICT, Interactive board.

\section{Giriş}

Son yıllarda birçok alanda meydana gelen gelişimler eğitim alanında da kendini göstermiş olup uzaktan eğitim ve e-öğrenme kavramlarının ortaya çıkmasına ve hızla gelişmesine neden olmuştur. Yazının icadından bu yana yaklaşık 6000 yıl geçti. İlk zamanlar eğitimde kum havuzları ve ağaç dalları kullanılırken zamanla bu araçlar yerini öğretmen ve ders kitaplarına bıraktı. Günümüz modern eğitimine kadar görsel ve işitsel araçlar (bilgisayar, tablet, internet vb.) kullanılarak gelinmiştir (Baytekin, 2004). Derslerde kullanılan araç-gereç sayısı arttıkça öğrenme işlevine katılan duyu sayısı da artmaktadır ki bu da fazla ve kalıcı öğrenmeye yardımcı olmaktadır (Sağlam, 2007).

Eskiden eğitimde haritalar, kitaplar ve yazı tahtaları gibi araçlar kullanılırken şimdilerde tabletler, bilgisayarlar, projeksiyon cihazları, tepe gözler ve etkileşimli tahtalar kullanılmaktadır. Etkileşimli tahtalar birçok modern sınıf araç gerecini (yazı tahtası, resimler, haritalar, hesap makinesi, video, müzik, internet vb.) içinde barındırmaktadır (Erduran ve Tataroğlu, 2009). Etkileşimli tahtalar 1980'li yıllarda ortaya çıkmıştır Etkileşimli tahtaların ortaya çıkması öğrenme işlevine katkı sağlamıştır. Eğitim dahil olmak üzere bir çok sektörde denenmiş ve olumlu sonuçlar ortaya çıktığından dolayı eğitimde yaygın kullanılır hale gelmiştir (Odabaşı, 2012). Etkileşimli tahtaların birden fazla işlevi olduğundan dolayı farklı öğrenme yöntemlerini destekleyerek, öğrencilerin hem öğretmenleriyle hem de birbirleriyle etkileşimlerini, anlama düzeylerini arttırmaktadır (Barak, 2007).

$\mathrm{Bu}$ tarz teknolojilerin kullanılmasıyla öğrencilerin düşünme yetenekleri geliştirilmiş olacaktır. AB ülkelerindeki okulların \%70'inde ve İngiltere, Japonya ve ABD’ deki okulların da \%90'nında etkileşimli tahta kullanılmaktadır (Odabaşı, 2012). 
Bu çalışmada Peace With ICT isimli AB projesi kapsamında İtalya, Slovenya, Romanya ve Türkiye'de çalışan eğitmenlerin etkileşimli tahtaya yönelik tutumlarını ortaya koymak için istatistiksel bir veri analizi çalışması yapılmıştır.

Peace With ICT projesi ile mesleki ve teknik eğitimde çalışan öğretmenlerin, eğitimin kalitesini arttırabilmeleri için teknolojik araçları eğitime adapte etmeyi amaçlamaktadır.

\section{Literatür Taraması}

Günümüz dünyasında teknolojinin sunduğu firsatlar insanların yaşamını kolaylaştırmaktadır. Ekonomi, sağlık ve iletişim gibi birçok sektörde teknoloji etkin bir biçimde kullanılmaktadır. İş dünyasının gelişimi, bu sektörlerde teknolojiden ne kadar yararlanıldığına bağlıdır (Friedman, 2005).

Teknolojinin özel sektörde birçok alana entegre olduğu bir çağda eğitim alanın bundan uzak kalması düşünülemez. Bu anlamda ülkemizde ve dünyada teknolojinin eğitim- öğretim ortamına entegre edilebilmesi adına çeşitli projeler sunulmaktadır. 1980 yılında Apple’s Classrooms of Tomorrow (ACOT, Apple'ın Geleceğin Sınıfları) ve 2000 yılında Preparing Tomorrow's Teachers to Use Technology (PT3, Geleceğin Öğretmenlerini Teknoloji Kullanımına Hazırlama) isimli projeler, 2008 yılında Portekiz'in tüm öğrencilere dizüstü bilgisayar verilmesi amacıyla hazırlanan Macellan projesi (Fourgous, 2010), Güney Kore’nin tüm okul kitaplarını elektronik ortama taşıması ve her öğrenciye tablet bilgisayar vermesi (Kim ve Jung, 2010) farklı ülkelerde teknolojinin eğitime entegrasyonuna ne kadar önem verildiğini göstermektedir.

$\mathrm{Bu}$ tarz projelerin hayata geçirilebilmesi için çok geniş bütçelere ihtiyaç vardır. 19952001 yılları arasında Amerika Birleşik Devletleri (ABD) eğitim teknolojilerine yaklaşık 729 milyon dolar harcadığını belirtmiştir (Russell, O’Dwyer, Bebell ve Tao, 2007). 2003-2004 yılında ise 7.8 milyar dolarlık bir yatırımla eğitim-öğretimin gelişimine katkı sağlamıştır (Quality Education Data Report, 2004).

ABD’nin Maine Eyaletinde 2002 yılında tüm ortaokul öğrencilerine ve öğretmenlerine, North Carolina Eyaletindeki ortaokul öğrencilerinden 1700'üne, New Hampshire Eyaletindeki 6. Sınıf öğrencilerine, Kentucky Eyaletindeki (2004) başarısız ve/veya evinde internet bağlantısı olmayan ortaokul öğrenci ve öğretmenlerine 3200 adet dizüstü bilgisayar dağıtılmıştır (News Report, 2007). 
Tayland hükümeti 2012 yılında "Her çocuğa bir tablet bilgisayar" adlı projeyle 1 milyon öğrenciye tablet dağıtmayı hedeflemiştir. Bu proje için yaklaşık 47 milyon avroluk kaynak ayrılmıştır (Lesardoises, 2012).

Ülkemizde de benzer projelerle eğitim teknolojileri entegrasyonu çalışmaları sürdürülmektedir. Örneğin, 1998-2007 yılları arasında Temel Eğitimi Geliştirme Projesi (TEGEP) kapsamında ülkemizdeki okullarda Bilgi İletişim Teknolojileri (BİT) sınıfları oluşturulmuştur. Milli Eğitim Bakanlığı (MEB) ülkemizdeki yaklaşık 5800 okula 7100 adet BİT sınıfı kurmuştur ve bu sınıflar bilgisayar, etkileşimli tahta, projeksiyon cihazı ve çoklu ortam cihazlarıyla donatılmıştır (MEB, 2012a). 2012 yılında başlatılan Fatih projesi kapsamında teknolojiyle uyumlu içerik geliştirme ve 10.6 milyon tabletin ayrıca 470.000 etkileşimli tahtanın okullara dağıtılması hedeflenmektedir. Aynı zamanda kurulan 110 adet eğitim merkezinde 705.000 öğretmene eğitim verilmesi hedefler içerisindedir. Ayrıca Fatih projesinin uygulama sürecinde öğretmenlerin, öğrencilerin ve idarecilerin yaşayabileceği sorunları çözme adına çalışmalar yapılmaktadır (Ayvacı ve Bakırcı, 2014).

Yürektürk ve Coşkun (2020) Türkçe öğretmenlerinin teknolojik araçları derslerinde kullanımına yönelik yapmış oldukları çalışmada öğretmenlerin bu konuda kendilerini yetersiz hissettikleri ve orta düzeyde kullandıklarını belirtmişlerdir.

Şahin ve Namlı'nın (2019) öğretmen adaylarının eğitimde teknolojik araçların kullanıma yönelik fikirlerini tespit etmek adına yaptıkları çalışmada adayların teknolojik araç olarak çoğunlukla tablet kullanmayı tercih ettikleri sonucunu çıkarmışlardır. Ayrıca erkek adayların eğitimde teknolojik araçları kullanmaya daha meyilli olduklarını belirtmişlerdir.

Akgün ve Yücekaya'nın (2015), Özcan ve Polat (2014), öğrenci ve öğretmen katılımcılar üzerinde gerçekleştirdiği etkileşimli tahta kullanımına yönelik çalışmada, etkileşimli tahtanın öğrenciler üzerinde anlamlı ve olumlu etki bıraktığı sonucuna varmışlardır. Ayrıcı öğretmen görüşlerinin incelenmesi sonucunda etkileşimli tahtanın motivasyonu arttırdığını ve konuların öğrenilmesinde kalıcı bir etki bıraktığını ortaya koymuşlardır. MannyIkan, Tikochinski, Zorman ve Dagan (2011) yaptıkları çalışmada, 2008 yılında dünya genelinde 60 ülkede çalışan bir eğitim organizasyonu İsrail'deki altı ortaokul ve lisede kullanılmak üzere 10 etkileşimli tahta, 32 dizüstü bilgisayar, internet bağlantısı ve iletişim yazılımı dağıtmıştır. Ayrıca öğretmen için bir eğitim programı vermiştir. 2 yıl boyunca bu çalışma kapsamında bu okulları incelemişlerdir. Çalışma sonuçlarına göre; etkileşimli tahtayla çalışırken öğrenci motivasyonunun ve öğrencinin öğrenme sürecine katılımının arttığı ayrıca öğretmenler üzerinde aşırı yüklenme hissinin oluştuğunu görmüşlerdir. 
Özkan ve Yalçınkaya'nın (2014) yaptıkları çalışmada ortaöğretimdeki öğretmenlerin etkileşimli tahta kullanımındaki öz yeterliliklerine; cinsiyet, hizmet yılı, okul türü, branş gibi çeşitli değişkenler açısından farklılık olup olmadığını incelemişlerdir. İnceleme sonucuna göre cinsiyet, yaş ve hizmet yılı değişkenlerinin etkileşimli tahta kullanım öz yeterliliği üzerinde anlamlı bir fark yarattığı görülmüştür.

Al-Qirim (2011), Bilgi Teknolojileri Fakültesindeki öğretimde etkileşimli tahtanın etkinliğini değerlendirmesi adına bir çalışma yapmıştır. Bu çalışmaya göre, etkileşimli tahtanın öğretimde kullanılmasına engel olan birkaç sorun vardı. Bunlar; uyumluluk ve karmaşıklık sorunlarıdır. Öğretmenler kendilerini geliştirip etkileşimli tahtayı tüm fonksiyonlarıyla kullanmadıkça öğrenciler üzerinde etkisinin çok az olduğunu ortaya çıkarmıştır. İlköğretimden üniversiteye kadar çok çeşitli dersler vardır ve bu derslerin içeriğine göre etkileşimli tahtaların özelleştirilmesinin gerektiğini vurgulamıştır.

\section{Yöntem}

2019 y1lında Türkiye, İtalya, Slovenya ve Romanya ülkelerindeki öğretmenlerin farkındalık eğitimi çerçevesinde etkileşimli tahtaya olan tutumlarını incelemeyi amaçlayan bu çalışmada nicel araştırma yöntemlerinden biri olan deneysel desenlerden tek bir grup üzerinde ön test-son test deneysel deseni uygulanmıştır. Uygulanan deseni tek bir grup üzerinde, deneklerin bağımlı değişkene ilişkin ölçümleri farkındalık eğitimi öncesi ön test ve sonrasında son test olmak üzere tüm katılımcılardan edinilmektedir.

Çalışma örneklemini Türkiye, İtalya, Slovenya ve Romanya ülkelerindeki projenin ortağı olan okullarda görev yapan 271 eğitimci oluşturmaktadır. Katılımcıların demografik özellikleri Tablo 1'de sunulmuştur.

Tablo 1. Katılımcılara İlişkin Demografik Bilgiler

\begin{tabular}{llccc}
\hline Değişken & Ülke & $\boldsymbol{f}$ & $\boldsymbol{\%}$ \\
\hline Ülke & İtalya & 45 & 16,6 \\
\cline { 2 - 4 } & Slovenya & 50 & 18,5 \\
\cline { 2 - 5 } & Romanya & 107 & 39,5 \\
\cline { 2 - 5 } & Türkiye & 69 & 25,5 \\
\hline Cinsiyet & Kadın & 792 & 70,8 \\
\cline { 2 - 4 } & Erkek & 8 & 29,2 \\
\hline Yaş & $26-30$ yaş & & 3,0 \\
\hline
\end{tabular}




\begin{tabular}{llccc}
\hline & $31-35$ yaş & 22 & 8,1 \\
\cline { 2 - 4 } & $36-40$ yaş & 63 & 23,2 \\
\cline { 2 - 4 } & $41+$ yaş & 178 & 65,7 \\
\hline Eğitim Seviyesi & Ön Lisans & 35 & 12,9 \\
\cline { 2 - 4 } & Lisans & 149 & 55,0 \\
\cline { 2 - 4 } & Yüksek Lisans & 70 & 29,5 \\
\cline { 2 - 4 } & Doktora & 7 & 2,6
\end{tabular}

Tablo 1' incelendiğinde, dört farklı ülkeden 192'si kadın, 79'u erkek olmak üzere toplam 271 kişiden oluştuğu görülecektir. Çalışma örneklemindeki eğitmenlerin yaş aralığı 26 ile $41+$ arasında değişmektedir.

Çalışmadaki verileri oluşturan, ülke, cinsiyet, yaş ve eğitim seviyesi gibi kişisel bilgilerin toplanması noktasında araştırmacılar tarafından geliştirilen kişisel bilgi formu, tutumlarını belirlemek için de Elaziz (2008) tarafından geliştirilen LCD Panel Etkileşimli Tahta Tutum Ölçeği kullanılmıştır. İki bölümden oluşan tutum ölçeğinin ilk bölümü katılımcıların demografik verileri, diğer bölümde ise etkileşimli tahtaya yönelik tutumlarını belirlemek için 5'li likert tipi ölçme yöntemiyle hazırlanmış sorular bulunmaktadır. LCD Panel Etkileşimli Tahta Tutum Ölçeğinin güvenilirlik değeri 0.92 olarak elde edilmiştir. Araştırmada verilerin analizinde; ön test ve son test değerlerinin karşılaştırılması için T-testi, kişisel bilgiler formundaki değişkenler ile etkileşimli tahtaya yönelik tutumları arasında anlamlı bir fark olup olmadığını anlamak için de ANOVA testi kullanılmıştır.

\section{Bulgular}

Araştırmada proje kapsamındaki ortak kuruluşlarda görev yapan eğitmenlerin etkileşimli tahtaya yönelik tutumlarını belirlemek amacıyla yapılan testin sonuçları Tablo 2'de sunulmuştur.

Tablo 2. Etkileşimli Tahta Tutum Ölçeği Ön test-Son test sonuçları

\begin{tabular}{ccccc}
\hline & Ort. & $\mathbf{N}$ & Std. Sapma & Std. Ort. Hata \\
\hline Ön Test & 2,16 & 270 & 1,08 &, 06 \\
\hline Son Test & 3,06 & 270 & 1,05 &, 06 \\
\hline
\end{tabular}

Tablo 2'de tüm ülkelerin eğitim öncesi ve eğitim sonrası ölçümlerin Ortalamaları (Ort.), Birim Sayıları (N), Standart Sapma (Std. Deviation) ve Standart Hata Değerleri (Std. Error Mean) verilmiştir.

Tüm ülkelerin eğitim öncesi (ön-test) ortalamaları 2.1691 iken, eğitim sonrası (sontest) ortalamaları 3.0642'dir. Ortalamalarda ortaya çıkan farkın istatistiksel olarak 
YYÜ Eğitim Fakültesi Dergisi (YYU Journal of Education Faculty), 2021; 18(1)494-521,http://efdergi.yyu.edu.tr,

anlamlılığının anlaşılabilmesi için t- testi yapılmış ve elde dilen sonuçlar Tablo 3'de verilmiştir.

Tablo 3. Etkileşimli Tahta Tutum Ölçeği Ön test-Son test sonuçları

\begin{tabular}{|c|c|c|c|c|c|c|c|c|}
\hline & \multicolumn{5}{|c|}{ Eşleştirilmiş Farklılıklar } & \multirow[b]{3}{*}{$\mathbf{t}$} & \multirow[b]{3}{*}{ sd } & \multirow[b]{3}{*}{ p. } \\
\hline & \multirow[b]{2}{*}{ Ort. } & \multirow[b]{2}{*}{ Std. Sapma } & \multirow{2}{*}{$\begin{array}{l}\text { Std. Hata } \\
\text { Ort. }\end{array}$} & \multicolumn{2}{|c|}{$\begin{array}{l}\text { 95\% Farkın } \\
\text { Güven Aralığı }\end{array}$} & & & \\
\hline & & & & Düşük & Yüksek & & & \\
\hline Ön Test - Son Test & $\begin{array}{l}-89 \\
\end{array}$ & 1,54 & ,09 & $-1,08$ &,- 71 & $-9,52$ & 269 & 000 \\
\hline
\end{tabular}

Tablo 3 incelendiğinde, anlamlılık değeri \%5'den küçük $(\mathrm{p}<.05)$ olduğu için Eğitim Öncesi puan ortalamaları ile Eğitim Sonrası puan ortalamaları arasında anlamlı bir fark vardır. Bu fark Tablo 3'de Ort. kısmında da görülmektedir. Sonuç olarak eğitim, katılımcılar üzerinde olumlu bir etki sağlamıştır. Katılımcıların etkileşimli tahtaya yönelik tutumları olumlu yönde artmıştır.

Tablo 4. Katılımcı ülkelerin Etkileşimli Tahta Tutum Ölçeği Ön test-Son test sonuçları

\begin{tabular}{llllcc}
\hline \multirow{2}{*}{ Türkiye } & & Ort. & N & Std. Sapma & Std. Ort. Hata \\
\hline \multirow{2}{*}{ Romanya } & Ön Test & 2,36 & 69 &, 95 &, 11 \\
\cline { 2 - 6 } & Son Test & 2,9 & 69 &, 92 &, 11 \\
\cline { 2 - 6 } & Ön Test & 2,12 & 105 & 1,28 &, 12 \\
\cline { 2 - 6 } Slovenya Test & 3,72 & 105 &, 86 &, 08 \\
\cline { 2 - 6 } & Ön Test & 1,70 & 50 &, 86 &, 12 \\
\cline { 2 - 6 } & Son Test & 2,12 & 50 &, 78 &, 11 \\
\hline \multirow{2}{*}{ İtalya } & Ön Test & 2,49 & 45 &, 82 &, 13 \\
\cline { 2 - 6 } & Son Test & 2,84 & 45 &, 90 & \\
\hline
\end{tabular}

Ön test-Son test ortalama değerlerine bakıldığında Türkiye'nin Eğitim Öncesi 2.3627, Eğitim Sonrası 2.9165, Romanya'nın Eğitim Öncesi 2.1238, Eğitim Sonras1 3.7249, Slovenya'nın Eğitim Öncesi 1.7082, Eğitim Sonrası 2.1211, İtalya'nın Eğitim Öncesi 2.4938, Eğitim Sonrası 2.8411'dir. Ortalamalarda artış görülmektedir ancak daha bilimsel ve kesin sonuç elde etmek için Tablo 5'in incelenmesi gerekmektedir.

Tablo 5. Katılımcı ülkelerin Etkileşimli Tahta Tutum Ölçeği Ön test-Son test sonuçları

\begin{tabular}{|c|c|c|c|c|c|c|c|c|}
\hline & \multicolumn{5}{|c|}{ Eşleştirilmiş Farklılıklar } & \multirow[b]{4}{*}{$\mathbf{t}$} & \multirow[b]{4}{*}{ sd } & \multirow[b]{4}{*}{ p. } \\
\hline & \multirow[b]{3}{*}{ Ort. } & \multirow[b]{3}{*}{ Std. Sapma } & \multirow{3}{*}{$\begin{array}{c}\text { Std. Hata } \\
\text { Ort. }\end{array}$} & \multirow{2}{*}{\multicolumn{2}{|c|}{$\begin{array}{c}\text { 95\% Farkın } \\
\text { Güven Aralığı }\end{array}$}} & & & \\
\hline & & & & & & & & \\
\hline & & & & Düşük & Yüksek & & & \\
\hline Türkiye Ön Test- Son Test &,- 55 & 1,51 & ,18 &,- 91 &,- 18 & $-3,03$ & 68 & ,003 \\
\hline Romanya Ön Test- Son Test & $-1,60$ & 1,52 & ,14 & $-1,89$ & $-1,30$ & $-10,74$ & 104 & 000 \\
\hline Slovenya Ön Test- Son Test &,- 41 & 1,06 & ,15 &,- 71 &,- 11 & $-2,75$ & 49 & ,008 \\
\hline İtalya Ön Test- Son Test &,- 34 & 1,29 & ,19 &,- 73 & 04 & $-1,80$ & 44 & 041 \\
\hline
\end{tabular}

Tablo 5 incelendiğinde tüm ülkelerin anlamlılık değerlerinin \%5'den küçük olduğu görülmektedir. Bu durum katılımcı ülkelerin Eğitim Öncesi puan ortalamaları ile Eğitim 
Sonrası puan ortalamaları arasında anlamlı bir farkın var olduğunu göstermektedir. Sonuç olarak eğitim, tüm katılımcılar üzerinde olumlu bir etki sağlamıştır, tüm katılımcıların etkileşimli tahtaya yönelik tutumlarını olumlu yönde arttırmıştır. Ön test ve Son test üzerinde yapılan Anova testi (Ön test $\mathrm{p}=.001$ ve Son test $\mathrm{p}=.001$ ) sonuçlarında $\mathrm{p}$ değerlerinin \%5’den küçük olduğu görülmektedir. Anlamlılık düzeylerini öğrenebilmek için Post Hoc Test’e bakilmalıdır (Tablo 6).

Tablo 6. Ülke bazlı etkileşimli tahta tutum değerlerinin sıralanması Post Hoc Tests - Coklu Karșılaștırma

\begin{tabular}{|c|c|c|c|c|c|c|c|}
\hline \multicolumn{8}{|c|}{ Bağımlı Değiş̧ken: } \\
\hline \multicolumn{2}{|c|}{ Etkileşimli Tahta Tutum } & \multicolumn{3}{|c|}{ Ön Test } & \multicolumn{3}{|c|}{ Son Test } \\
\hline \multirow[b]{2}{*}{ (I) Ülke } & \multirow[b]{2}{*}{ (J) Ülke } & \multicolumn{3}{|c|}{ Std. } & \multicolumn{3}{|c|}{ Std. } \\
\hline & & Ort. Fark (I-J) & Hata & p. & Ort. Fark (I-J) & Hata & p. \\
\hline \multirow{3}{*}{ İtalya } & Slovenya & ,78* & ,17 & ,000 & ,74* & ,17 & ,000 \\
\hline & Romanya & ,37 & ,17 & ,190 &,$- 88^{*}$ & ,15 & 000 \\
\hline & Türkiye & ,13 & ,16 & ,969 &,- 07 & ,16 & ,970 \\
\hline \multirow{3}{*}{ Slovenya } & İtalya &,$- 78^{*}$ & ,17 & ,000 &,$- 74^{*}$ & ,17 & ,000 \\
\hline & $\overline{\text { Romanya }}$ &,- 41 & ,17 & ,108 & $-1,62^{*}$ & ,14 & ,000 \\
\hline & $\begin{array}{l}\text { Türkiye } \\
\end{array}$ &,$- 65^{*}$ & ,16 & ,001 &,$- 81^{*}$ & ,16 & ,000 \\
\hline \multirow{3}{*}{ Romanya } & İtalya &,- 37 & ,17 & ,190 & ,88* & ,15 & 000 \\
\hline & Slovenya & ,41 & ,17 & ,108 & $1,62^{*}$ & ,14 & 000 \\
\hline & $\begin{array}{l}\text { Türkiye } \\
\end{array}$ &,- 24 & ,16 & ,636 &, $80^{*}$ & ,13 & 000 \\
\hline \multirow{3}{*}{ Türkiye } & İtalya &,- 13 & ,16 & ,969 & ,07 & ,16 & 99 \\
\hline & Slovenya & ,65* & ,16 & ,001 &, $81^{*}$ & ,16 & , 000 \\
\hline & Romanya & ,24 & ,16 & ,636 &,$- 80^{*}$ & ,13 & ,000 \\
\hline
\end{tabular}

Tablo 6'da, Ön test ve Son test sütunlarındaki p sütun değerlerine bakıldığgnda bazı değerlerin \%5'den küçük ( $\mathrm{p}<.05)$ olduğu görülmektedir. Bu durum etkileşimli tahta kullanma becerileri ile katılımcı ülkeler arasında anlamlı bir farkın olduğunu göstermektedir. Bu farkın hangi ülkenin lehine-aleyhine olduğu Ort. Fark sütuna bakarak tespit edilir. Ort. Fark sütunundaki değerin yönü (pozitif-negatif) ülkeler arasındaki etkileşimli tahta kullanma becerisinin hangi ülkenin lehine-aleyhine olduğunu göstermektedir.

Tablo 6’da, ön test sütunundaki p sütun değerlerine bakıldığında katılımcı ülkeler ile etkileşimli tahtaya yönelik tutumları arasında anlamlı bir fark olduğu görülmektedir. Bu farka göre etkileşimli tahtaya yönelik tutumlarda ilk sırayı İtalya, ikinci sırayı Türkiye, üçüncü sırayı Romanya ve son sırayı da Slovenya'nın aldığı görülmüştür. 
Tablo 6'da, ön test sütunundaki p sütun değerlerine bakıldığında katılımcı ülkeler ile etkileşimli tahtaya yönelik tutumları arasında anlamlı bir fark olduğu görülmektedir. Bu farka göre etkileşimli tahtaya yönelik tutumlarda ilk sırayı Romanya, ikinci sırayı Türkiye, üçüncü sırayı İtalya ve son sırayı da Slovenya'nın aldığı görülmüştür.

Ön test ve son test verileri birlikte değerlendirildiğinde tüm ülkelerde etkileşimli tahtaya yönelik tutumlarında olumlu yönde artış olduğu görülmektedir.

Ölçekte kullanılan sorulardan Mesleki deneyim değişkeninin; “Hangi sıklıkla bilgisayar, dizüstü bilgisayar veya tablet kullaniyorsunuz?”, “Öğretim teknolojilerinin eğitim için gerekliliğine inanıyor musunuz?” ve "Hangi sıklıkla etkileşimli tahta kullanıyorsunuz?" değişkenleriyle aralarındaki ilişkiyi tespit üzere MANOVA analizi yapılmıştır. MANOVA birden fazla değişkene yönelik ortalamaların karşılaştırılmasında kullanılan bir istatistiki analizdir.

Tablo 7. Ön test ve Son test mesleki deneyim değişkeninin etki düzeyleri Pillai’s Trace test sonuçları

\begin{tabular}{|c|c|c|c|c|c|c|c|c|c|c|c|}
\hline \multicolumn{2}{|c|}{ Çok Değişkenli Test } & \multicolumn{6}{|c|}{ Ön Test } & \multicolumn{4}{|c|}{ Son Test } \\
\hline \multirow[b]{3}{*}{ Etki } & & \multirow[b]{3}{*}{ Değer } & \multirow[b]{3}{*}{$\mathbf{F}$} & \multicolumn{4}{|c|}{ Kısmi } & \multirow{2}{*}{\multicolumn{3}{|c|}{ Hipotez }} & \multirow{3}{*}{$\begin{array}{r}\text { Kismı } \\
\text { Eta } \\
\text { Kare }\end{array}$} \\
\hline & & & & Hipotez & & Eta & & & & & \\
\hline & & & & df & p. & Kare & Value & $\mathbf{F}$ & df & p. & \\
\hline \multirow[t]{4}{*}{ Intercept } & $\begin{array}{l}\text { Pillai's } \\
\text { Trace }\end{array}$ & ,97 & $3252,483^{b}$ & 3,00 & ,000 & ,97 & ,98 & $5720,701^{b}$ & 3,00 & ,000 & ,98 \\
\hline & $\begin{array}{l}\text { Wilks' } \\
\text { Lambda }\end{array}$ & ,02 & $3252,483^{b}$ & 3,00 & ,000 & ,97 & ,01 & $5720,701^{b}$ & 3,00 & ,000 & ,98 \\
\hline & $\begin{array}{l}\text { Hotelling's } \\
\text { Trace }\end{array}$ & 36,96 & $3252,483^{b}$ & 3,00 & ,000 & 97 & 65,25 & $5720,701^{b}$ & 3,00 & ,000 & ,98 \\
\hline & $\begin{array}{l}\text { Roy's } \\
\text { Largest } \\
\text { Root }\end{array}$ & 36,96 & $3252,483^{b}$ & 3,00 & ,000 & 97 & 65,25 & $5720,701^{b}$ & 3,00 & ,000 & ,98 \\
\hline \multirow[t]{4}{*}{$\begin{array}{l}\text { Mesleki } \\
\text { Deneyim }\end{array}$} & $\begin{array}{l}\text { Pillai's } \\
\text { Trace }\end{array}$ & ,06 & 1,484 & 12,00 & 124 & ,02 & ,06 & 1,343 & 12,00 & 189 & ,02 \\
\hline & $\begin{array}{l}\text { Wilks' } \\
\text { Lambda }\end{array}$ & ,93 & 1,491 & 12,00 & ,122 & ,02 & ,94 & 1,352 & 12,00 & ,184 & ,02 \\
\hline & $\begin{array}{l}\text { Hotelling's } \\
\text { Trace }\end{array}$ & ,06 & 1,495 & 12,00 & ,120 & ,02 & ,06 & 1,361 & 12,00 & 179 & ,02 \\
\hline & $\begin{array}{l}\text { Roy's } \\
\text { Largest } \\
\text { Root }\end{array}$ & ,05 & $3,467^{c}$ & 4,00 & ,009 & ,05 & ,05 & $3,573^{c}$ & 4,00 & 007 & ,05 \\
\hline
\end{tabular}

Varyans homojenliği ihlal edildiğinden (Ön Test’te $\mathrm{p}=.001$ ve Son Test’te $\mathrm{p}=.030$ ) ve eşit olmayan gruplar olduğundan dolayı Pillai’s Trace test değerine bakılır (Tablo 7). Bu değerlerin (Ön Test’te 0.022 ve $p=.124$, Son Test'te 0.020 ve $\mathrm{p}=.189$ ) anlamlı düzeyde olmadığı görülmektedir. Yani Mesleki deneyim değişkeninin; "Hangi sıklıkla bilgisayar, dizüstü bilgisayar veya tablet kullanıyorsunuz?”, “Öğretim teknolojilerinin ĕgitim için 
YYÜ Eğitim Fakültesi Dergisi (YYU Journal of Education Faculty), 2021; 18(1)494-521,http://efdergi.yyu.edu.tr,

doi:10.33711/yyuefd.919391 Araştırma Makalesi $\quad$ ISSN: 1305-2020

gerekliliğine inanıyor musunuz?" ve "Hangi sıklıkla etkileşimli tahta kullanıyorsunuz?” değişkenleriyle aralarında anlamlı bir fark yoktur. Değişkenler arası etkilenme değeri Ön Test için \% 0.22 iken Son Test’te \% 0.20’dir. 
Tablo 8. Ön test ve son test mesleki deneyim değişkeninin etki düzeyleri

Değişkenler Arası Etki

Ön Test

Son Test

\begin{tabular}{|c|c|c|c|c|c|c|c|c|c|c|c|c|c|}
\hline \multirow[b]{2}{*}{ Kaynak } & \multirow{2}{*}{$\begin{array}{l}\text { Değişkenler Arası Etki } \\
\text { Bağımlı Değişken }\end{array}$} & \multicolumn{6}{|c|}{ Ön Test } & \multicolumn{6}{|c|}{ Son Test } \\
\hline & & $\begin{array}{c}\text { Type III } \\
\text { Karelerin } \\
\text { Top. }\end{array}$ & df & Ort. Kare & $\mathrm{F}$ & p. & $\begin{array}{l}\text { Kismi Eta } \\
\text { Kare }\end{array}$ & $\begin{array}{c}\text { Type III } \\
\text { Karelerin } \\
\text { Top. }\end{array}$ & df & Ort. Kare & $\mathrm{F}$ & p. & $\begin{array}{l}\text { Kismi Eta } \\
\text { Kare }\end{array}$ \\
\hline \multirow[t]{3}{*}{$\begin{array}{l}\text { Düzeltilmiş } \\
\text { Model }\end{array}$} & $\begin{array}{l}\text { Hangi sıklıkla bilgisayar, dizüstü bilgisayar } \\
\text { veya tablet kullanıyor sunuz? }\end{array}$ & $2,196^{\mathrm{a}}$ & 4 &, 54 & 1,18 & 320 &, 01 & $4,773^{\mathrm{a}}$ & 4 & 1,19 & 2,90 &, 022 &, 04 \\
\hline & $\begin{array}{l}\text { Öğretim teknolojilerinin eğitim için } \\
\text { gerekliliğine inanıyor musunuz? }\end{array}$ & $1,571^{\mathrm{b}}$ & 4 & ,39 & ,32 & ,864 & ,00 & $3,876^{\mathrm{b}}$ & 4 & ,96 & 1,02 & ,394 & ,01 \\
\hline & $\begin{array}{l}\text { Hangi sıklıkla etkileşimli tahta kullanıyor } \\
\text { sunuz? }\end{array}$ & $21,921^{\mathrm{c}}$ & 4 & 5,48 & 3,45 & ,009 & ,04 &, $674^{c}$ & 4 & 16 & 13 & ,968 & ,00 \\
\hline \multirow[t]{3}{*}{ Intercept } & $\begin{array}{l}\text { Hangi sıklıkla bilgisayar, dizüstü bilgisayar } \\
\text { veya tablet kullanıyorsunuz? }\end{array}$ & 4408,29 & 1 & 4408,29 & 9477,12 &, 000 & ,97 & 5056,33 & 1 & 5056,33 & 12315,37 &, 000 & ,97 \\
\hline & $\begin{array}{l}\text { Öğretim teknolojilerinin eğitim için } \\
\text { gerekliliğine inanıyor musunuz? }\end{array}$ & 2389,74 & 1 & 2389,74 & 1949,11 & ,000 & ,88 & 3839,84 & 1 & 3839,84 & 4070,39 & ,000 & 93 \\
\hline & $\begin{array}{l}\text { Hangi ssklıkla etkileşimli tahta } \\
\text { kullanıyorsunuz? }\end{array}$ & 1366,78 & 1 & 1366,78 & 860,46 &, 000 & ,76 & 3334,34 & 1 & 3334,34 & 2739,09 &, 000 & ,91 \\
\hline \multirow[t]{3}{*}{$\begin{array}{l}\text { Mesleki } \\
\text { Deneyim }\end{array}$} & $\begin{array}{l}\text { Hangi sıklıkla bilgisayar, dizüstü bilgisayar } \\
\text { veya tablet kullanıyorsunuz? }\end{array}$ & 2,19 & 4 & ,54 & 1,18 & ,320 & ,01 & 4,77 & 4 & 1,19 & 2,90 & ,022 & ,04 \\
\hline & $\begin{array}{l}\text { Öğretim teknolojilerinin eğitim için } \\
\text { gerekliliğine inanıyor musunuz? }\end{array}$ & 1,57 & 4 & ,39 & ,32 & ,864 & ,00 & 3,87 & 4 & ,96 & 1,02 & ,394 & ,01 \\
\hline & $\begin{array}{l}\text { Hangi stklıkla etkileşimli tahta } \\
\text { kullanıyorsunuz? }\end{array}$ & 21,92 & 4 & 5,48 & 3,45 & ,009 &, 04 & ,67 & 4 & ,16 & ,13 & ,968 & ,00 \\
\hline \multirow[t]{3}{*}{ Hata } & $\begin{array}{l}\text { Hangi sıklıkla bilgisayar, dizüstü bilgisayar } \\
\text { veya tablet kullanıyorsunuz? }\end{array}$ & 123,73 & 266 & 46 & & & & 108,80 & 265 & ,41 & & & \\
\hline & $\begin{array}{l}\text { Öğretim teknolojilerinin eğitim için } \\
\text { gerekliliğine inanyyor musunuz? }\end{array}$ & 326,13 & 266 & 1,22 & & & & 249,99 & 265 & ,94 & & & \\
\hline & $\begin{array}{l}\text { Hangi siklıkla etkileşimli tahta } \\
\text { kullanıyorsunuz? }\end{array}$ & 422,52 & 266 & 1,58 & & & & 322,58 & 265 & 1,21 & & & \\
\hline \multirow[t]{3}{*}{ Toplam } & $\begin{array}{l}\text { Hangi sıklıkla bilgisayar, dizüstü bilgisayar } \\
\text { veya tablet kullanıyorsunuz? }\end{array}$ & 6257,00 & 271 & & & & & 5947,00 & 270 & & & & \\
\hline & $\begin{array}{l}\text { Öğretim teknolojilerinin eğitim için } \\
\text { gerekliliğine inanıor musunuz? }\end{array}$ & 3672,00 & 271 & & & & & 4526,00 & 270 & & & & \\
\hline & $\begin{array}{l}\text { Hangi ssklıkla etkileşimli tahta } \\
\text { kullanıyorsunuz? }\end{array}$ & 2368,00 & 271 & & & & & 4079,00 & 270 & & & & \\
\hline \multirow[t]{3}{*}{$\begin{array}{l}\text { Düzeltilmiş } \\
\text { Toplam }\end{array}$} & $\begin{array}{l}\text { Hangi sıklıkla bilgisayar, dizüstü bilgisayar } \\
\text { veya tablet kullanıyorsunuz? }\end{array}$ & 125,92 & 270 & & & & & 113,57 & 269 & & & & \\
\hline & $\begin{array}{l}\text { Öğretim teknolojilerinin eğitim için } \\
\text { gerekliliğine inanıor musunuz? }\end{array}$ & 327,70 & 270 & & & & & 253,86 & 269 & & & & \\
\hline & $\begin{array}{l}\text { Hangi sıklıkla etkileşimli tahta } \\
\text { kullanıyorsunuz? }\end{array}$ & 444,44 & 270 & & & & & 323,26 & 269 & & & & \\
\hline
\end{tabular}


Tablo 8'deki Kısmi eta-kare sütunu incelendiğinde Mesleki deneyim değişkenin, diğer değişkenlerden ne kadar etkilendiği görülmektedir. "Hangi sıklıkla bilgisayar, dizüstü bilgisayar veya tablet kullanıyorsunuz?” ‘a etkisi Ön Test için \% 0.17 iken Son Test için \% 0.42 , “Öğretim teknolojilerinin ĕgitim için gerekliliğine inanıyor musunuz?” sorusuna etkisi Ön Test için \% 0.05 iken Son Test için \% 0.15 ve “Hangi sıklıkla etkileşimli tahta kullanıyorsunuz?” sorusuna etkisi Ön Test için \% 0.49 iken Son Test için \% 0.02'dir. Bu değerlerden ön test için, "Hangi sıklıkla etkileşimli tahta kullanıyorsunuz?” ve son test için de “Hangi sıklıkla etkileşimli tahta kullanıyorsunuz?” sorularına verilen cevaplar ile mesleki deneyim arasında anlamlı bir fark olduğu görülmektedir. Bu farkın kaynağını bulmak için Post hoc testleri yapılır. Varyans homojenliği ihlal edildiğinden dolayı Tamhane test değerleri incelenir.

Tablo 9. Ön test mesleki deneyim değişkeninin etki düzeyleri Post hoc test sonuçları

\begin{tabular}{|c|c|c|c|c|c|}
\hline \multicolumn{3}{|c|}{ Tamhane - Ön Test } & \multicolumn{3}{|c|}{ Çoklu Karşılaştırma } \\
\hline Bağımlı & (I) Mesleki & & & & \\
\hline Değişken & Den. & (J) Mesleki Den. & Ort. Fark (I-J) & Std. Hata & p. \\
\hline \multirow{20}{*}{ 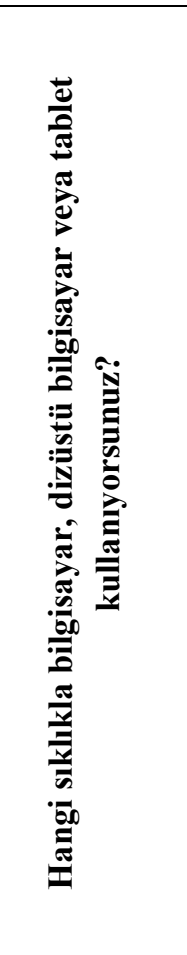 } & \multirow[t]{4}{*}{$1-5$} & $6-10$ &,- 03 & ,07 & 1,00 \\
\hline & & $11-15$ & ,11 & ,08 & ,837 \\
\hline & & $16-20$ & ,23 & , 10 & 276 \\
\hline & & $21+$ & 25 & 11 & ,452 \\
\hline & \multirow[t]{4}{*}{$6-10$} & $1-5$ & ,03 & ,07 & 1,00 \\
\hline & & $11-15$ & ,15 & ,07 & ,333 \\
\hline & & $16-20$ & 27 & 10 & 077 \\
\hline & & $21+$ & ,25 & ,10 & 170 \\
\hline & \multirow[t]{4}{*}{$11-15$} & $1-5$ &,- 11 & ,08 & ,837 \\
\hline & & $6-10$ &,- 15 & ,07 & ,333 \\
\hline & & $16-20$ & 11 & ,10 & ,956 \\
\hline & & $21+$ & ,09 & 11 & ,990 \\
\hline & \multirow[t]{4}{*}{$16-20$} & $1-5$ &,- 23 & ,10 & 276 \\
\hline & & $6-10$ &,- 27 & ,10 & ,077 \\
\hline & & $11-15$ &,- 11 & 10 & 956 \\
\hline & & $21+$ &,- 01 & ,12 & 1,00 \\
\hline & \multirow[t]{4}{*}{$21+$} & $1-5$ &,- 21 & 11 & ,452 \\
\hline & & 6-10 &,- 25 & ,10 & ,170 \\
\hline & & $11-15$ &,- 09 & ,11 & ,990 \\
\hline & & $16-20$ & ,01 & ,12 & 1,00 \\
\hline \multirow{9}{*}{ 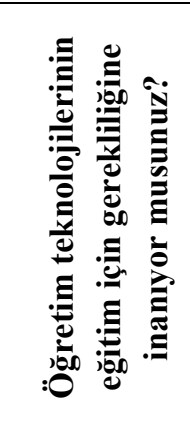 } & \multirow[t]{4}{*}{$1-5$} & 6-10 &,- 06 & ,21 & 1,00 \\
\hline & & $11-15$ & 11 & ,18 & 1,00 \\
\hline & & $16-20$ & ,27 & ,19 & ,837 \\
\hline & & $21+$ & ,30 & ,19 & ,745 \\
\hline & \multirow[t]{4}{*}{$6-10$} & $1-5$ & ,06 & ,21 & 1,00 \\
\hline & & $11-15$ & ,18 & ,18 & ,986 \\
\hline & & $16-20$ & ,33 & ,19 & ,623 \\
\hline & & $21+$ & ,36 & ,19 & ,517 \\
\hline & $11-15$ & $1-5$ &,- 11 & ,18 & 1,00 \\
\hline
\end{tabular}




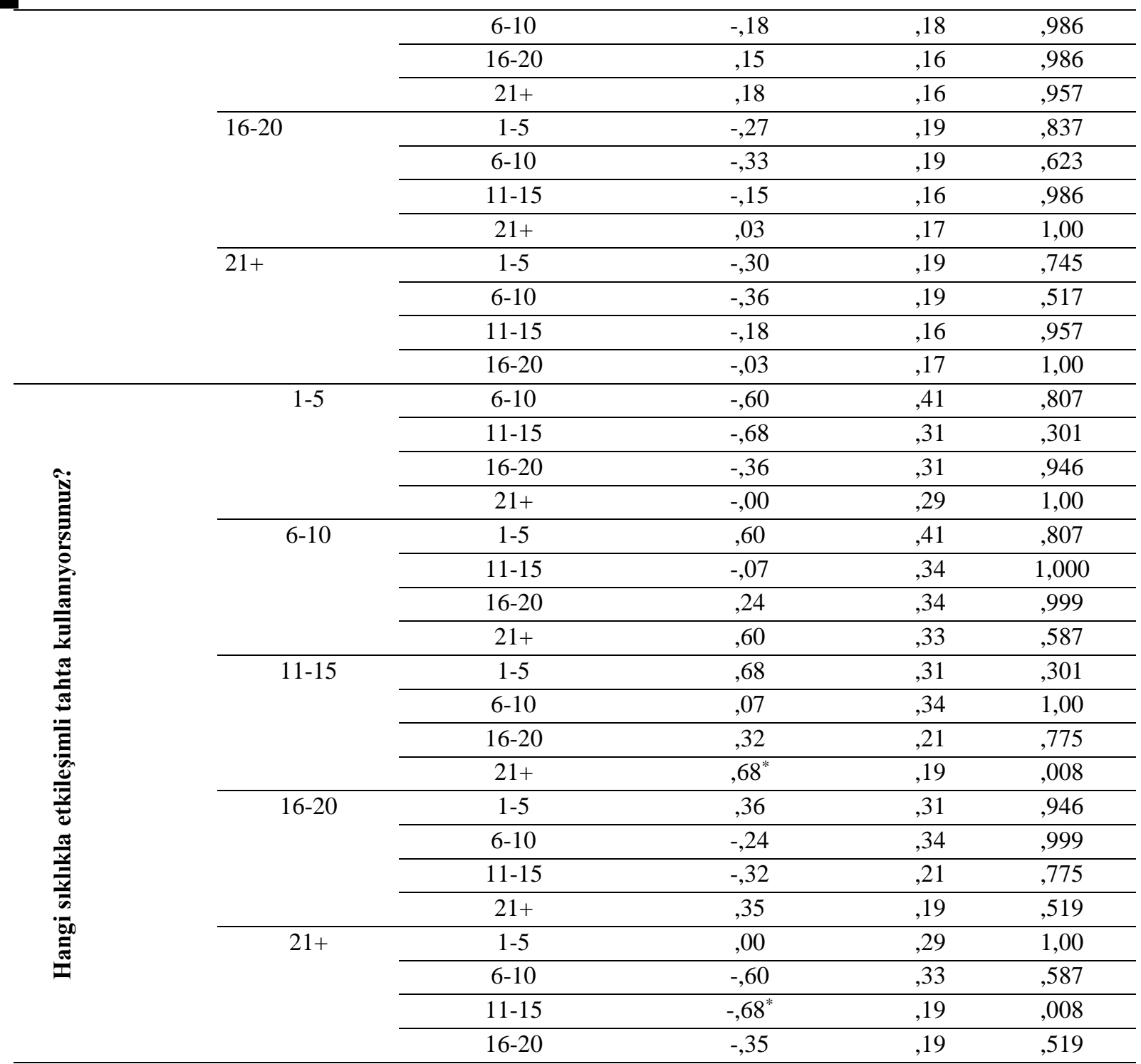

Varyanslar eşit dağılmadığı için Tamhane testi seçilmiştir (Tablo 9). Ön test verileri üzerinde yapılan analizler sonucunda; Mesleki deneyim değişkeninin, "Hangi sıklıkla bilgisayar, dizüstü bilgisayar veya tablet kullanıyorsunuz?” ve “Öğretim teknolojilerinin eğitim için gerekliliğine inanıyor musunuz?” değişkenleriyle aralarında anlamlı bir fark yoktur. Ancak “Hangi sıklıkla etkileşimli tahta kullanıyorsunuz?" değişkeniyle anlamlı bir fark vardır ve bu farka göre 11-15 y1llık mesleki deneyime sahip kişilerin 21+ yıllık deneyime sahip kişilere göre etkileşimli tahtayı daha sık kullanmaktadırlar.

Tablo 10. Son test mesleki deneyim değişkeninin etki düzeyleri Tamhane test sonuçları Tamhane - Son Test Çoklu Karşılaştırma

\begin{tabular}{|c|c|c|c|c|}
\hline \multirow[b]{2}{*}{ Bağımlı Değişken } & \multirow[b]{2}{*}{ (J) Mesleki Den. } & \multicolumn{3}{|c|}{ Std. } \\
\hline & & Ort. Fark (I-J) & Hata & p. \\
\hline \multirow{2}{*}{ 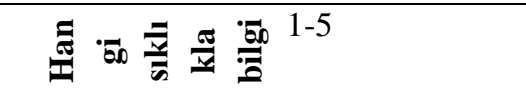 } & $6-10$ &,- 16 & ,14 & ,952 \\
\hline & 11-15 &,- 13 & ,15 & ,994 \\
\hline
\end{tabular}


YYÜ Eğitim Fakültesi Dergisi (YYU Journal of Education Faculty), 2021; 18(1)494-521,http://efdergi.yyu.edu.tr,

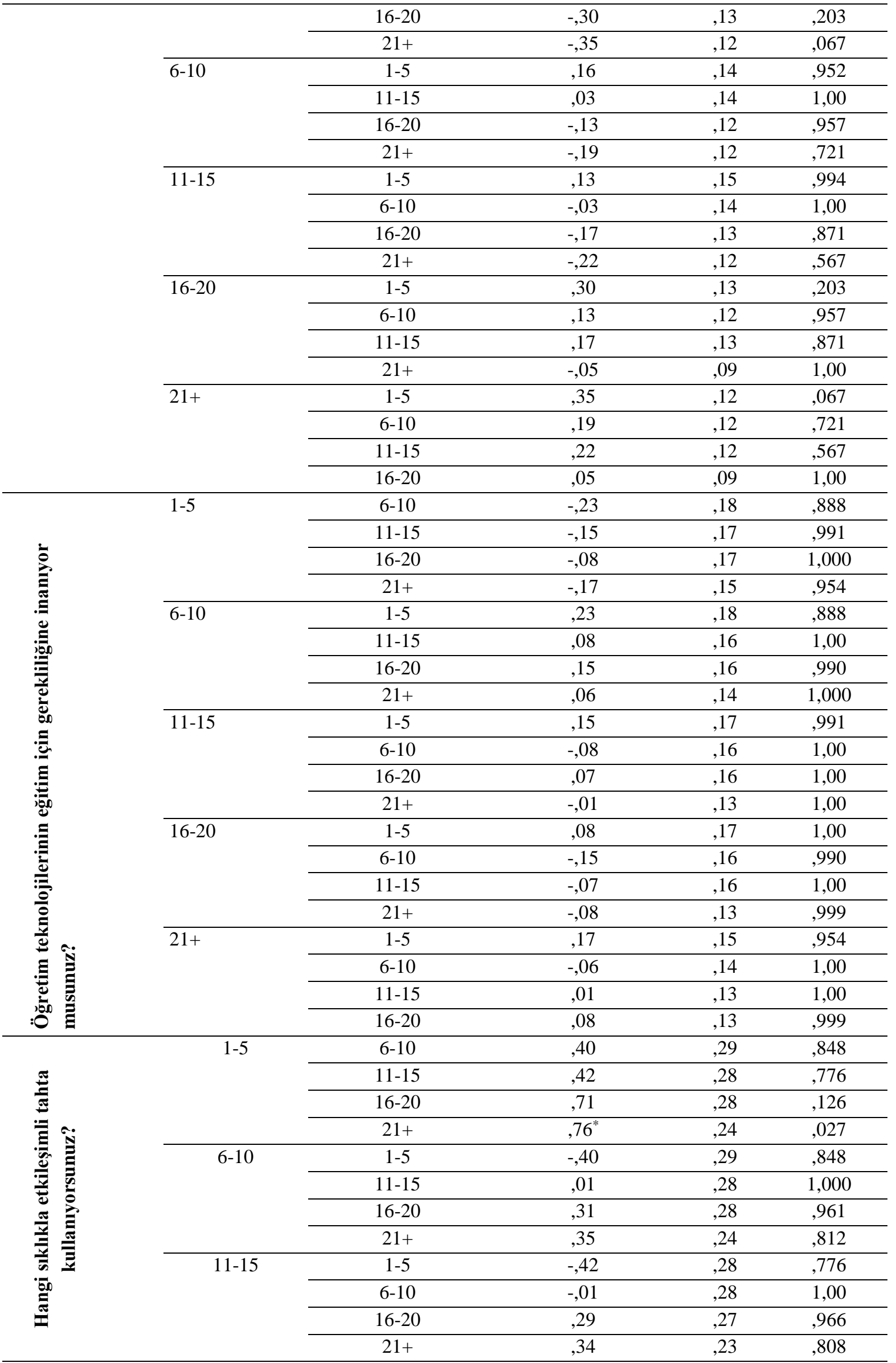




\begin{tabular}{ccccc} 
16-20 & $1-5$ &,- 71 &, 28 &, 126 \\
\cline { 2 - 5 } & $6-10$ &,- 31 &, 28 &, 961 \\
\cline { 2 - 5 } & $11-15$ &,- 29 &, 27 &, 966 \\
\hline $21+$ & $21+$ &, 04 &, 23 & 1,00 \\
\cline { 2 - 5 } & $1-5$ &,$- 76^{*}$ &, 24 &, 027 \\
\cline { 2 - 5 } & $6-10$ &,- 35 &, 24 &, 812 \\
\cline { 2 - 5 } & $11-15$ &,- 34 &, 23 &, 808 \\
\cline { 2 - 5 } & $16-20$ &,- 04 &, 23 & 1,00 \\
\hline
\end{tabular}

Son test verileri üzerinde yapılan analizle sonucunda; Mesleki deneyim değişkeninin, “Hangi sıklıkla bilgisayar, dizüstü bilgisayar veya tablet kullanıyorsunuz?” ve “Öğretim teknolojilerinin ĕgitim için gerekliliğine inanıyor musunuz?” değişkenleriyle aralarında anlamlı bir fark yoktur ama "Hangi sıklıkla etkileşimli tahta kullanıyorsunuz?” değişkeniyle anlamlı bir fark vardır ve bu farka göre 1-5 yıllık mesleki deneyime sahip kişilerin 21+ yıllık deneyime sahip kişilere göre etkileşimli tahtayı daha sık kullanmaktadır (Tablo 10).

Ölçekte kullanılan sorulardan Ülke değişkeninin; “Hangi sıklıkla bilgisayar, dizüstü bilgisayar veya tablet kullanıyorsunuz?”, “Öğretim teknolojilerinin eğitim için gerekliliğine inanıyor musunuz?” ve “Hangi sıklıkla etkileşimli tahta kullanıyorsunuz?” değişkenleriyle aralarındaki ilişkiyi tespit üzere MANOVA analizi yapılmıştır.

Tablo 17. Ön test ve Son test ülke değişkeninin etki düzeyleri Pillai’s Trace test sonuçları

\begin{tabular}{|c|c|c|c|c|c|c|c|c|c|c|}
\hline \multicolumn{2}{|c|}{$\begin{array}{c}\text { Çok Değişkenli } \\
\text { Test }\end{array}$} & \multicolumn{5}{|c|}{ Ön Test } & \multicolumn{4}{|c|}{ Son Test } \\
\hline \multirow{2}{*}{\multicolumn{2}{|c|}{ Etki }} & & & & Kısmi & & & & & \\
\hline & & $\mathbf{F}$ & $\begin{array}{l}\text { Hipotez } \\
\text { df }\end{array}$ & p. & $\begin{array}{c}\text { Eta } \\
\text { Kare }\end{array}$ & Value & $\mathbf{F}$ & $\begin{array}{l}\text { Hipotez } \\
\text { df }\end{array}$ & p. & $\begin{array}{c}\text { Kismı Eta } \\
\text { Kare }\end{array}$ \\
\hline \multirow[t]{4}{*}{ Intercept } & $\begin{array}{l}\text { Pillai's } \\
\text { Trace }\end{array}$ & $4254,417^{b}$ & 3,00 & ,000 & ,98 & ,98 & $6373,307^{b}$ & 3,00 & ,000 & ,98 \\
\hline & $\begin{array}{l}\text { Wilks' } \\
\text { Lambda }\end{array}$ & $4254,417^{b}$ & 3,00 & ,000 & ,98 & ,01 & $6373,307^{b}$ & 3,00 & ,000 & ,98 \\
\hline & $\begin{array}{l}\text { Hotelling's } \\
\text { Trace }\end{array}$ & $4254,417^{b}$ & 3,00 & ,000 & ,98 & 72,97 & $6373,307^{b}$ & 3,00 & ,000 & ,98 \\
\hline & $\begin{array}{l}\text { Roy's } \\
\text { Largest } \\
\text { Root }\end{array}$ & $4254,417^{b}$ & 3,00 & ,000 & ,98 & 72,97 & $6373,307^{b}$ & 3,00 & ,000 & 98 \\
\hline \multirow[t]{4}{*}{ Coutry } & $\begin{array}{l}\text { Pillai's } \\
\text { Trace }\end{array}$ & 8,744 & 9,00 & ,000 & ,08 & ,42 & 14,483 & 9,00 & ,000 & 14 \\
\hline & $\begin{array}{l}\text { Wilks' } \\
\text { Lambda }\end{array}$ & 9,007 & 9,00 & ,000 & ,09 & 60 & 16,557 & 9,00 & ,000 & ,15 \\
\hline & $\begin{array}{l}\text { Hotelling's } \\
\text { Trace }\end{array}$ & 9,078 & 9,00 & ,000 & ,09 & ,62 & 18,177 & 9,00 & ,000 & ,17 \\
\hline & $\begin{array}{l}\text { Roy's } \\
\text { Largest } \\
\text { Root }\end{array}$ & $16,476^{c}$ & 3,00 & ,000 & ,15 &, 55 & $49,182^{c}$ & 3,00 & ,000 & ,35 \\
\hline
\end{tabular}


Varyans homojenliği ihlal edildiğinden (Ön Test’te $\mathrm{p}=.001$ ve Son Test'te $\mathrm{p}=.030$ ) ve eşit olmayan gruplar olduğundan dolayı Pillai’s Trace test değerine bakılır (Tablo 17). Bu değerlerin (Ön Test’te 0.089 ve $\mathrm{p}=.001$, Son Test’te 0.141 ve $\mathrm{p}=.001$ ) anlamlı düzeyde olduğu görülmektedir. Yani Ülke değişkeninin; "Hangi sıklıkla bilgisayar, dizüstü bilgisayar veya tablet kullanıyorsunuz?”, “Öğretim teknolojilerinin ĕgitim için gerekliliğine inanıyor musunuz?” ve "Hangi sıklıkla etkileşimli tahta kullanıyorsunuz?” değişkenleriyle aralarında anlamlı bir fark vardır. Değişkenler arası etkilenme değeri Ön Test için \% 0.89 iken Son Test’te $\% 1.41^{\prime}$ dir. 
YÜ Eğitim Fakültesi Dergisi (YYU Journal of Education Faculty), 2021; 18(1)494-521,http://efdergi.yyu.edu.tr.

Tablo 18. Ön test ve Son test mesleki deneyim değişkeninin etki düzeyleri

\begin{tabular}{|c|c|c|c|c|c|c|c|c|c|c|c|c|c|}
\hline \multirow[b]{2}{*}{ Kaynak } & \multirow{2}{*}{$\begin{array}{l}\text { Değişkenler Arası Etki } \\
\text { Bağımlı Değişken }\end{array}$} & \multicolumn{6}{|c|}{ Ön Test } & \multicolumn{6}{|c|}{ Son Test } \\
\hline & & $\begin{array}{c}\text { Type III } \\
\text { Karelerin Top. }\end{array}$ & df & Ort. Kare & $\mathbf{F}$ & p. & $\begin{array}{c}\text { Kısmi Eta } \\
\text { Kare } \\
\end{array}$ & $\begin{array}{c}\text { Type III } \\
\text { Karelerin } \\
\text { Top. } \\
\end{array}$ & df & Ort. Kare & $\mathbf{F}$ & p. & $\begin{array}{l}\text { Kismi Eta } \\
\text { Kare }\end{array}$ \\
\hline \multirow[t]{3}{*}{$\begin{array}{l}\text { Düzeltilmiş } \\
\text { Model }\end{array}$} & $\begin{array}{l}\text { Hangi sıklıkla bilgisayar, dizüstü bilgisayar veya } \\
\text { tablet kullanıyorsunuz? }\end{array}$ & $6,902^{\mathrm{a}}$ & 3 & 2,30 & 5,16 & ,002 & ,05 & $14,526^{\mathrm{a}}$ & 3 & 4,84 & 12,93 & ,000 & ,12 \\
\hline & $\begin{array}{l}\text { Öğretim teknolojilerinin eğitim için gerekliliğine } \\
\text { inanıyor musunuz? }\end{array}$ & $16,660^{\mathrm{b}}$ & 3 & 5,55 & 4,76 & ,003 & ,05 & $7,785^{\mathrm{b}}$ & 3 & 2,59 & 4,45 & ,005 &, 04 \\
\hline & Hangi sıklıkla etkileşimli tahta kullanıyorsunuz? & $63,807^{c}$ & 3 & 21,26 & 14,91 & ,000 & ,14 & $144,337^{c}$ & 3 & 48,11 & 38,02 &, 000 & ,30 \\
\hline \multirow[t]{3}{*}{ Intercept } & $\begin{array}{l}\text { Hangi sıklıkla bilgisayar, dizüstü bilgisayar veya } \\
\text { tablet kullanıyorsunuz? }\end{array}$ & 5579,29 & 1 & 5579,29 & 12515,66 & ,000 & ,97 & 5304,69 & 1 & 5304,69 & 14174,67 &, 000 & ,98 \\
\hline & $\begin{array}{l}\text { Öğretim teknolojilerinin eğitim için gerekliliğine } \\
\text { inanıyor musunuz? }\end{array}$ & 2881,25 & 1 & 2881,25 & 2473,26 &, 000 & ,90 & 4231,01 & 1 & 4231,01 & 7259,24 & ,000 & ,96 \\
\hline & Hangi sıklıkla etkileşimli tahta kullanıyorsunuz? & 1736,83 & 1 & 1736,83 & 1218,31 &, 000 & 82 & 2514,51 & 1 & 2514,51 & 1987,03 &, 000 & ,88 \\
\hline \multirow[t]{3}{*}{$\begin{array}{l}\text { Mesleki } \\
\text { Deneyim }\end{array}$} & $\begin{array}{l}\text { Hangi sıklıkla bilgisayar, dizüstü bilgisayar veya } \\
\text { tablet kullanıyorsunuz? }\end{array}$ & 6,90 & 3 & 2,30 & 5,16 & ,002 & ,05 & 14,52 & 3 & 4,84 & 12,93 & , 000 & ,12 \\
\hline & $\begin{array}{l}\text { Öğretim teknolojilerinin eğitim için gerekliliğine } \\
\text { inanıyor musunuz? }\end{array}$ & 16,66 & 3 & 5,55 & 4,76 & ,003 & ,05 & 7,78 & 3 & 2,59 & 4,45 &, 005 &, 04 \\
\hline & Hangi sıklıkla etkileşimli tahta kullanıyorsunuz? & 63,80 & 3 & 21,26 & 14,91 & ,000 & 14 & 144,33 & 3 & 48,11 & 38,02 &, 000 & ,30 \\
\hline \multirow[t]{3}{*}{ Hata } & $\begin{array}{l}\text { Hangi sıklıkla bilgisayar, dizüstü bilgisayar veya } \\
\text { tablet kullanıyorsunuz? }\end{array}$ & 119,02 & 267 & ,44 & & & & 98,79 & 264 &, 37 & & & \\
\hline & $\begin{array}{l}\text { Öğretim teknolojilerinin eğitim için gerekliliğine } \\
\text { inanıyor musunuz? }\end{array}$ & 311,04 & 267 & 1,16 & & & & 153,87 & 264 &, 58 & & & \\
\hline & Hangi sıklıkla etkileşimli tahta kullanıyorsunuz? & 380,63 & 267 & 1,42 & & & & 334,08 & 264 & 1,26 & & & \\
\hline \multirow[t]{3}{*}{ Toplam } & $\begin{array}{l}\text { Hangi sıklıkla bilgisayar, dizüstü bilgisayar veya } \\
\text { tablet kullanıyorsunuz? }\end{array}$ & 6257,00 & 271 & & & & & 5897,00 & 268 & & & & \\
\hline & $\begin{array}{l}\text { Öğretim teknolojilerinin eğitim için gerekliliğine } \\
\text { inanıyor musunuz? }\end{array}$ & 3672,00 & 271 & & & & & 4960,00 & 268 & & & & \\
\hline & Hangi sıklıkla etkileşimli tahta kullanıyorsunuz? & 2368,00 & 271 & & & & & 3474,00 & 268 & & & & \\
\hline \multirow[t]{3}{*}{$\begin{array}{l}\text { Düzeltilmiş } \\
\text { Toplam }\end{array}$} & $\begin{array}{l}\text { Hangi sıklıkla bilgisayar, dizüstü bilgisayar veya } \\
\text { tablet kullanıyorsunuz? }\end{array}$ & 125,92 & 270 & & & & & 113,32 & 267 & & & & \\
\hline & $\begin{array}{l}\text { Öğretim teknolojilerinin eğitim için gerekliliğine } \\
\text { inanıyor musunuz? }\end{array}$ & 327,70 & 270 & & & & & 161,65 & 267 & & & & \\
\hline & Hangi sıklıkla etkileşimli tahta kullanıyorsunuz? & 444,44 & 270 & & & & & 478,41 & 267 & & & & \\
\hline
\end{tabular}


Tablo 18 incelendiğinde, "Hangi sıklıkla bilgisayar, dizüstü bilgisayar veya tablet kullanıyorsunuz?” (Ön Test için $\mathrm{p}=.002$, Son Test için $\mathrm{p}=.001$ ), “Öğretim teknolojilerinin eğitim için gerekliliğine inanıyor musunuz?” (Ön Test için $\mathrm{p}=.003$, Son Test için $\mathrm{p}=.005$ ) ve “Hangi sıklıkla etkileşimli tahta kullanıyorsunuz?” (Ön Test için $\mathrm{p}=.001$, Son Test için $\mathrm{p}=$ .001) faktörlerinde Ülke 'ye göre anlamlı bir farklılık olduğu görülmektedir. Ülkenin, “Hangi sıklıkla bilgisayar, dizüstü bilgisayar veya tablet kullanıyorsunuz?” ‘a etkisi Ön Test için \%0.55 iken Son Test için \% 1.28, “Öğretim teknolojilerinin ĕgitim için gerekliliğine inanıyor musunuz?” 'a etkisi Ön Test için \%0.51 iken Son Test için \%4.8 ve "Hangi sıklıkla etkileşimli tahta kullanıyorsunuz?” ‘a etkisi Ön Test için \% 1.44 iken Son Test için \% 3.02'dir. “Hangi sıklıkla bilgisayar, dizüstü bilgisayar veya tablet kullanıyorsunuz?”, “Öğretim teknolojilerinin eğitim için gerekliliğine inanıyor musunuz?" ve "Hangi sıklıkla etkileşimli tahta kullanıyorsunuz?” değişkenleri ile ülke değişkeni arasında anlamlı bir farkın olduğu görülmektedir. Bu farkın kaynağını bulmak için Post hoc test'i yapılır.

Tablo 19. Ön test ve son test ülke değişkeninin etki düzeyleri Tamhane test sonuçları

\begin{tabular}{|c|c|c|c|c|c|c|c|c|}
\hline \multicolumn{4}{|c|}{ Multiple Comparisons - Tamhane } & \multicolumn{2}{|c|}{ ÖnTest } & \multicolumn{3}{|c|}{ Son Test } \\
\hline $\begin{array}{l}\text { Bağımlı } \\
\text { Değişken }\end{array}$ & (I) Ülke & (J) Ülke & $\begin{array}{c}\text { Ort. Fark } \\
\text { (I-J) }\end{array}$ & $\begin{array}{c}\text { Std. } \\
\text { Hata }\end{array}$ & Sig. & $\begin{array}{c}\text { Ort. Fark } \\
\text { (I-J) }\end{array}$ & Std. Hata & Sig. \\
\hline \multirow{12}{*}{ 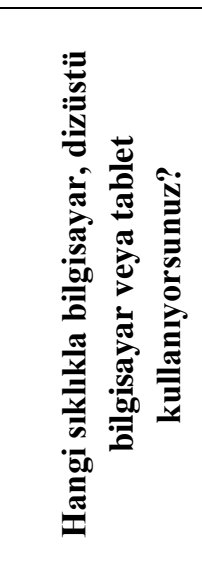 } & \multirow[t]{3}{*}{ İtalya } & Slovenya & $-0,03$ & 0,11 & 1,00 & 0,04 & 0,09 & ,999 \\
\hline & & Romanya & 0,28 & 0,11 & 0,05 & $37^{*}$ & 0,07 & ,000 \\
\hline & & Türkiye & $-0,06$ & 0,07 & 0,93 &, $60^{*}$ & 0,09 & ,000 \\
\hline & \multirow[t]{3}{*}{ Slovenya } & İtalya & 0,03 & 0,11 & 1,00 & $-0,04$ & 0,09 & ,999 \\
\hline & & Romanya & 0,31 & 0,12 & 0,06 & $33^{*}$ & 0,10 & ,009 \\
\hline & & Türkiye & $-0,03$ & 0,10 & 1,00 &, $57^{*}$ & 0,12 & ,000 \\
\hline & \multirow[t]{3}{*}{ Romanya } & İtalya & $-0,28$ & 0,11 & 0,05 &,$- 37^{*}$ & 0,07 & ,000 \\
\hline & & Slovenya & $-0,31$ & 0,12 & 0,06 &,$- 33^{*}$ & 0,10 & ,009 \\
\hline & & Türkiye &,$- 35^{*}$ & 0,10 & 0,00 & 0,23 & 0,11 & ,184 \\
\hline & \multirow[t]{3}{*}{ Türkiye } & İtalya & 0,06 & 0,07 & 0,93 &,$- 60^{*}$ & 0,09 & ,000 \\
\hline & & Slovenya & 0,03 & 0,10 & 1,00 &,$- 57^{*}$ & 0,12 &, 000 \\
\hline & & Romanya &, $35^{*}$ & 0,10 & 0,00 & $-0,23$ & 0,11 & 184 \\
\hline \multirow{12}{*}{ 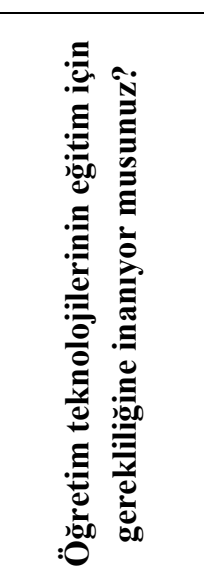 } & \multirow[t]{3}{*}{ İtalya } & Slovenya & 0,01 & 0,16 & 1,00 & $43^{*}$ & 0,15 & ,023 \\
\hline & & Romanya & $-0,05$ & 0,17 & 1,00 & $-0,03$ & 0,12 & 1,00 \\
\hline & & Türkiye & $-0,13$ & 0,16 & 0,97 & 0,05 & 0,13 & ,999 \\
\hline & \multirow[t]{3}{*}{ Slovenya } & İtalya & $-0,01$ & 0,16 & 1,00 &,$- 434^{*}$ & 0,15 &, 023 \\
\hline & & Romanya & $-0,06$ & 0,16 & 1,00 &,$- 46^{*}$ & 0,14 &, 005 \\
\hline & & Türkiye & $-0,14$ & 0,15 & 0,93 & $-0,38$ & 0,15 & ,058 \\
\hline & \multirow[t]{3}{*}{ Romanya } & Italya & 0,05 & 0,17 & 1,00 & 0,03 & 0,12 & 1,00 \\
\hline & & Slovenya & 0,06 & 0,16 & 1,00 & $46^{*}$ & 0,14 & ,005 \\
\hline & & Türkiye & $-0,08$ & 0,16 & 1,00 & 0,08 & 0,12 & ,985 \\
\hline & \multirow[t]{3}{*}{ Türkiye } & Italya & 0,13 & 0,16 & 0,97 & $-0,05$ & 0,13 & ,999 \\
\hline & & Slovenya & 0,14 & 0,15 & 0,93 & 0,38 & 0,15 & ,058 \\
\hline & & Romanya & 0,08 & 0,16 & 1,00 & $-0,08$ & 0,12 & 985 \\
\hline
\end{tabular}




\begin{tabular}{|c|c|c|c|c|c|c|c|c|}
\hline \multirow{12}{*}{ 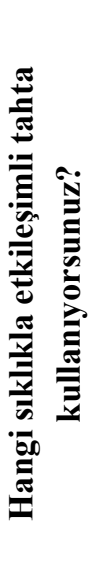 } & \multirow[t]{3}{*}{ İtalya } & Slovenya & $1,53^{*}$ & 0,27 & 0,00 & $1,59^{*}$ & 0,26 & 000 \\
\hline & & Romanya &, $77^{*}$ & 0,22 & 0,01 & 0,03 & 0,20 & 1,00 \\
\hline & & Türkiye & 0,40 & 0,26 & 0,57 &,$- 613^{*}$ & 0,21 & ,031 \\
\hline & \multirow[t]{3}{*}{ Slovenya } & İtalya & $-1,53^{*}$ & 0,27 & 0,00 & $-1,59^{*}$ & 0,26 & ,000 \\
\hline & & Romanya &,$- 75^{*}$ & 0,20 & 0,00 & $-1,55^{*}$ & 0,22 & ,000 \\
\hline & & Türkiye & $-1,13^{*}$ & 0,25 & 0,00 & $-2,20^{*}$ & 0,22 & , 000 \\
\hline & \multirow[t]{3}{*}{ Romanya } & İtalya &,$- 77^{*}$ & 0,22 & 0,01 & $-0,03$ & 0,20 & 1,00 \\
\hline & & Slovenya & $75^{*}$ & 0,20 & 0,00 & $1,55^{*}$ & 0,22 & ,000 \\
\hline & & Türkiye & $-0,38$ & 0,19 & 0,26 &,$- 64^{*}$ & 0,16 & 001 \\
\hline & \multirow[t]{3}{*}{ Türkiye } & İtalya & $-0,40$ & 0,26 & 0,57 & ,61 & 0,21 & 031 \\
\hline & & Slovenya & $1,13^{*}$ & 0,25 & 0,00 & $2,20^{*}$ & 0,22 & ,000 \\
\hline & & Romanya & 0,38 & 0,19 & 0,26 & $64^{*}$ & 0,16 & 001 \\
\hline
\end{tabular}

Tablo 19'da Ön Test ve Son Test 'deki Ülke değişkenin, “Hangi sıklıkla bilgisayar, dizüstü bilgisayar veya tablet kullanıyorsunuz?” ve “Öğretim teknolojilerinin ĕgitim için gerekliliğine inanıyor musunuz?" ve "Hangi slklkkla etkileşimli tahta kullanıyorsunuz?" değişkenleriyle aralarında anlamlılık düzeylerinin hangi ülkenin aleyhine ya da lehine olduğu görülmektedir. Ön test değerlerine bakıldığında Türkiye ile Romanya arasında, "Hangi sıklıkla bilgisayar, dizüstü bilgisayar veya tablet kullanıyorsunuz?” değişkenleri ile aralarında anlamlı bir fark var ve bu fark Türkiye lehinedir. Ayrıca İtalya ile Slovenya, İtalya ile Romanya ve Türkiye ile Slovenya arasında, "Hangi sıklıkla etkileşimli tahta kullanıyorsunuz?” değişkenleri ile aralarında anlamlı bir fark var ve bu fark İtalya-Slovenya için İtalya'nın lehine, İtalya-Romanya için İtalya'nın lehine ve Türkiye-Slovenya için Türkiye’nin lehinedir.

Son test değerlerine bakıldığında İtalya ile Romanya, İtalya ile Türkiye arasında, “Hangi sıklıkla bilgisayar, dizüstü bilgisayar veya tablet kullanıyorsunuz?” değişkenleri ile aralarında anlamlı bir fark var ve bu fark İtalya-Romanya için İtalya'nın lehine ve İtalyaTürkiye için de yine İtalya'nın lehinedir. İtalya ile Slovenya ve Romanya ile Slovenya arasında, "Öğretim teknolojilerinin eğitim için gerekliliğine inanıyor musunuz?" değişkenleri ile aralarında anlamlı bir fark var ve bu fark İtalya-Slovenya için İtalya'nın lehine, SlovenyaRomanya için Romanya'nın lehinedir. Ayrıca İtalya ile Slovenya, Slovenya ile Romanya ve Türkiye ile Slovenya arasında, "Hangi sıklıkla etkileşimli tahta kullanıyorsunuz?” değişkenleri ile aralarında anlamlı bir fark var ve bu fark İtalya-Slovenya için İtalya'nın lehine, SlovenyaRomanya için Romanya'nın lehine ve Türkiye-Slovenya için Türkiye’nin lehinedir.

Tablo 20. Ön test ve son test ülke bazlı siralama 


\begin{tabular}{|c|c|c|c|c|c|c|c|}
\hline & Ülke & Ortalama & Std. Sapma & $\mathbf{N}$ & Ortalama & Std. Sapma & $\mathbf{N}$ \\
\hline \multirow{5}{*}{$\begin{array}{l}\text { Hangi sıklıkla bilgisayar, } \\
\text { dizüstü bilgisayar veya } \\
\text { tablet kullanıyorsunuz? }\end{array}$} & İtalya & 4,84 & 0,42 & 45,00 & 4,96 & 0,21 & 45,00 \\
\hline & Slovenya & 4,88 & 0,63 & 50,00 & 4,92 & 0,57 & 49,00 \\
\hline & Romanya & 4,56 & 0,89 & 107,00 & 4,58 & 0,66 & 105,00 \\
\hline & Türkiye & 4,91 & 0,33 & 69,00 & 4,35 & 0,72 & 69,00 \\
\hline & Total & 4,76 & 0,68 & 271,00 & 4,65 & 0,65 & 268,00 \\
\hline \multirow{5}{*}{$\begin{array}{l}\text { Öğretim teknolojilerinin } \\
\text { eğitim için gerekliliğine } \\
\text { inanıyor musunuz? }\end{array}$} & İtalya & 3,93 & 0,81 & 45,00 & 4,31 & 0,63 & 45,00 \\
\hline & Slovenya & 3,92 & 0,78 & 50,00 & 3,88 & 0,78 & 49,00 \\
\hline & Romanya & 3,98 & 1,26 & 107,00 & 4,34 & 0,79 & 105,00 \\
\hline & Türkiye & 4,06 & 0,84 & 69,00 & 4,26 & 0,78 & 69,00 \\
\hline & Total & 3,98 & 1,01 & 271,00 & 4,23 & 0,78 & 268,00 \\
\hline \multirow{5}{*}{$\begin{array}{l}\text { Hangi sıklıkla etkileşimli } \\
\text { tahta kullanıyorsunuz? }\end{array}$} & İtalya & 3,36 & 1,35 & 45,00 & 3,49 & 1,18 & 45,00 \\
\hline & Slovenya & 1,82 & 1,29 & 50,00 & 1,90 & 1,33 & 49,00 \\
\hline & Romanya & 2,58 & 0,91 & 107,00 & 3,46 & 1,07 & 105,00 \\
\hline & Türkiye & 2,96 & 1,39 & 69,00 & 4,10 & 1,00 & 69,00 \\
\hline & Total & 2,66 & 1,28 & 271,00 & 3,34 & 1,34 & 268,00 \\
\hline
\end{tabular}

Tablo 20'de Ülke bazlı "Hangi sıkllkla bilgisayar, dizüstü bilgisayar veya tablet kullanıyorsunuz?” ve “Öğretim teknolojilerinin eğitim için gerekliliğine inanıyor musunuz?” ve "Hangi sıklıkla etkileşimli tahta kullanıyorsunuz?" değişkenlerine verilen cevapların istatistikî değerleri görülmektedir. Bu değerlere göre farkındalık eğitimi sonrasında ülke bazlı sıralamanın ne düzeyde olduğu görülebilmektedir.

\section{Tartışma ve Sonuç}

Teknolojinin, eğitim ve öğretim ortamına entegrasyonu 30 yıldan fazla bir süredir tartışılmaktadır (Gurer ve Curaoğlu, 2016). Bu entegrasyon çoğunlukla eğitim ve öğretim ortamını iyileştirerek farklı öğrenme stillerine sahip öğrencilerin motivasyonunu ve derse aktif katılımı arttırmaktadır (Beeland, 2011). Teknoloji entegrasyonun başarılı olabilmesi için öğretmenlerin kendi branşlarında uygun teknolojiyi kullanabilmeleri gerekmektedir. Öğretmenlerin branş bazında kendilerine uygun teknolojiyi kullanabilmeleri için de özel eğitimlere ihtiyaç duyulmaktadır. Bu doğrultuda katılımcılara verilen eğitim sonrasında etkileşimli tahtaya yönelik tutumlarda farklılıklar tespit edilmiştir.

Mesleki deneyim değişkeninin; "Hangi sıklıkla bilgisayar, dizüstü bilgisayar veya tablet kullanıyorsunuz?”, “Öğretim teknolojilerinin ĕgitim için gerekliliğine inanıyor musunuz?” ve “Hangi sıklıkla etkileşimli tahta kullanıyorsunuz?” değişkenleriyle aralarındaki ilişkiyi anlamak üzere yapılan testler sonucunda farkındalık eğitimi öncesinde 11-15 yıl arası mesleki deneyime sahip kişilerin 21+ mesleki deneyime sahip kişilere göre daha sık etkileşimli tahtayı kullandığı görülürken farkındalık eğitimi sonrasında 1-5 yıllık mesleki deneyime sahip kişilerin de etkileşimli tahtayı daha sık kullandığı ve eğitim sonrasında etkileşimli tahtayı aktif 
kullanan kişi sayısının arttığı görülmektedir. Mesleki deneyim ile bilişim teknolojileri arasında anlamlı bir ilişkinin olduğu ve bu ilişkinin pozitif yönde olabilmesi için bilişim teknolojileri üzerine daha çok eğitimin verilmesi gerektiği sonucu çıkarılmaktadır.

Ülke değişkeninin; "Hangi sıklıkla bilgisayar, dizüstü bilgisayar veya tablet kullanıyorsunuz?”, “Öğretim teknolojilerinin ĕgitim için gerekliliğine inanıyor musunuz?” ve “Hangi sıklıkla etkileşimli tahta kullanıyorsunuz?” değişkenleriyle aralarındaki ilişkiyi anlamak üzere yapılan testler sonucunda "Hangi sıklıkla bilgisayar, dizüstü bilgisayar veya tablet kullanıyorsunuz?” değişkenine verilen cevaplar doğrultusunda ülke bazlı en iyi gelişme İtalya'da görülmektedir. "Öğretim teknolojilerinin eğitim için gerekliliğine inanıyor musunuz?” değişkenine verilen cevaplar doğrultusunda ülke bazlı en iyi gelişme İtalya'da görülmektedir. “Hangi sıklıkla etkileşimli tahta kullanıyorsunuz?” değişkenine verilen cevaplar doğrultusunda ülke bazlı en iyi gelişme Türkiye'de görülmektedir. Her üç soruya da verilen cevaplar doğrultusunda her bir ülkenin az da olsa bir gelişme gösterdiği, bu gelişmenin derecesini belirleyen şey ise; farkındalık eğitimine katılım ve aldığı eğitimi uygulayabilme durumu olmuştur.

Ülkelerdeki ortak kuruluşlarda çalışan eğitmenlerin etkileşimli tahtaya yönelik tutumlarını ortaya koymak için farkındalık eğitimi öncesinde yapılan Ön test ve sonrasında yapılan Son test sonuçları kıyaslandığında Romanya'nın Etkileşimli tahtaya yönelik tutumlarında olumlu yönde artış olmuştur ve bu artış miktarı diğer ülkelere oranla daha fazladır. Ayrıca İtalya, Slovenya ve Türkiye'de de Etkileşimli tahtaya yönelik tutumlarında artış olduğu görülmüştür. Farkındalık eğitimi öncesinde ve sonrasında yapılan istatistiksel analizlerin sonucuna göre katılımcı ülkelerin toplamda \%32.02 gelişim gösterdikleri görülmüştür.

Fourgous (2010), Kim ve Jung (2010) ve Russell ve ark. (2007) bilişim teknolojilerinin bir ülkenin gelişiminde ne kadar büyük bir etkiye sahip olduğunu belirtmiş ve bu yönde okul kitaplarının dijital ortama taşıyarak, öğrencilere ve eğitimcilere tablet bilgisayar dağıtarak (Lesardoises, 2012), interneti olmayan evlere internet bağlayarak (News Report, 2007) ve BİT sınıfları oluşturarak (MEB, 2012a) eğitime büyük bir destek sağlanacağını belirtmişlerdir. Bu çalışma doğrultusunda verilen farkındalık eğitimi katılımcıları dijital teknolojileri kullanmada cesaretlendirmiştir.

Yücekaya ve Akgün (2015) ile Polat ve Özcan’nın (2014) yaptıkları çalışmada etkileşimli tahtaların öğrencilerin motivasyonunu arttırdığını ve konuların öğrenilmesinde kalıcı etki bıraktığını belirtmişlerdir. Öğretmenlerin kendilerini geliştirip etkileşimli tahtayı 
YYÜ Ĕ̆itim Fakültesi Dergisi (YYU Journal of Education Faculty), 2021; 18(1)494-521,http://efdergi.yyu.edu.tr,

kendi sınıflarında etkili bir şekilde kullanmadıklarında öğrencilerin gelişimine pek fazla katkı sağlamadıkları görülmüştür (Al-Qirim (2011)). Öğretmenlerin BİT’i derslerinde etkin bir şekilde kullanabilmesi için bu tarz farkındalık eğitimlerinin ya da hizmet içi eğitimlerinin verilmesi gerekmektedir.

\section{Öneriler}

Çalışma kapsamında örneklendirilen proje ve bu projeye benzer teknolojik cihazların kullanım kapasitelerinin arttırılmasına yönelik projelerin yaygınlaştırılması eğitimin kalitesini ve öğrenci gelişimini olumlu yönde etkileyeceği düşünülmektedir.

\section{Makalenin Bilimdeki Konumu}

Bilgisayar ve teknolojik ürünlerin etkin kullanımı.

\section{Makalenin Bilimdeki Özgünlüğü}

Yapılan çalışma AB destekli uluslararası bir projedir. Uluslararası bir proje olmasından dolayı birden fazla ülkedeki öğretmenlerin etkileşimli tahta ve teknolojik araçlara karşı tutumunu içermektedir. Bu sebepten dolayı literatürde özgün bir yer tutmaktadır. 


\section{Kaynaklar}

Akgün, M. ve Yücekaya Koru, G. (2015). Akıllı tahta kullanımına yönelik öğrenci tutumu ve öğretmen görüşlerinin incelenmesi (Ankara ili Örneği). Qualitative Studies, (1), 1-12.

Ayvacı, H. Ş., Bakırcı, H. ve Başak, M. H. (2014). Fatih projesinin uygulama sürecinde ortaya çıkan sorunların idareciler öğretmenler ve öğrenciler tarafından değerlendirilmesi. Yüzüncü Yıl Üniversitesi Eğitim Fakültesi Dergisi, 11(1), 20-46.

Al-Qirim, N. (2011). Determinants of interactive whiteboard success in teaching in higher education institutions. Computer \& Education, 56(3), 827-838

Barak, M. (2007). Transition from traditional to 1ct-enhanced learning environments in undergraduate chemistry courses. Computers \& Education, 48, 30-43.

Baytekin, Ç. (2004). Öğrenme öğretme teknikleri ve materyal geliştirme (2. Bask1). Anı Yayınc1lık, Ankara.

Beeland, W. D. (2011). Student engagement, visual learning and technology: can interactive whiteboards help? http://teach.valdosta.edu/are/Artmanscrpt/vol1no1/beeland_am.pdf adresinden alınmıştır.

Elaziz, M. F. (2008). Attitudes of students and teachers towards the use of interactive whiteboardsın efl classrooms. Yayınlanmış yüksek lisans tezi, Bilkent Üniversitesi, Ankara, Türkiye.

Erduran, A. ve Tataroğlu, B. (2009). Eğitimde akıllı tahta kullanımına ilişkin fen ve matematik öğretmen görüşlerinin karşılaştırılması. İnternational Technology Conferance (IETC). Ankara.

Fourgous, J. M. (2010). Réussir l’école numérique. http://www.crie.min-edu.pt/files/@ crie/1269619873_Rapport_mission_fourgous.pdf adresinden alınmıştır.

Friedman, T. L. (2005). The world is flat: A brief history of the twenty-first century. New York, NY: Farrar, Straus and Giroux.

Gurer, M.D. ve Curaoglu, O. (2016). Pre-service teachers' perception of technology use in classroom. In G. Chamblee \& L. Langub (Eds.), Proceedings of Society for Information Technology \& Teacher Education International Conference 2016 (2854-2859). Publisher: Chesapeake, VA: Association for the Advancement of Computing in Education (AACE). ISBN 978-1-939797-13-1.

Kim, J. ve Jung, H-Y. (2010). South Korean digital textbook project. Computers in the Schools, 27(3-4), 247-265. 
Lesardoises. (2012). Les tablettes dans l'éducation la Thaïlande. http://lesardoises. com/11123/les-tablettes-dans-leducation-la-thailande-franchit-le-pas-pour-328millions-de-dollars.html adresinden alınmıştır.

Lewin, C.,Somekh, B. ve Steadman, S. (2008). Embedding interactive whiteboards in teaching and learning. The Process of Change in Pedagogic, Education and Information Technologies, 13, 291-303.

Manny-Ikan, E., Tikochinski, T. B., Zorman, R. ve Dagan, O. (2011). Using the interactive white board in teaching and learning: An evaluation of the SMART CLASSROOM pilot project. Interdisciplinary Journal of E-Learning \& Learning Objects, 7, 249-273.

MEB (2012a). Milli Eğitim Bakanlığı tamamlanan projeler. http://projeler.meb.gov.tr/pkmtr/ Erişim Tarihi: 25.12 .2020$.

News Report. (2007). Louisiana Laptop Initiative provides laptops to students in public schools. http://www.govtech.com/e-government/ Louisiana-Laptop-Initiative-ProvidesLaptops-to.html adresinden alınmıştır.

Odabaş1, F., (2012). Bilgisayar destekli eğitim. Bölüm 8. http://w2.anadolu.edu.tr/aos/kitap/ IOLTP/2276/unite08.pdf.

Polat, S., Özcan, A. (2014). Akıllı tahta kullanımıyla ilgili sınıf öğretmenlerinin görüşleri. Kastamonu Ë̆itim Dergisi, 22 (2) , 439-455.

Qirim, N (2011). Determinats of interactive white board success in teching in higher education institution, Computers Education, 56, 827-838.

Quality Education Data (QED) Report. (2004). 2004- 2005 technology purchasing forecast (10th ed.). New York: Scholastic Company.

Russell, M., O’Dwyer, L., Bebell, D., ve Tao, W. (2007). How teachers uses of technology vary by tenure and longevity. Journal of Educational Computing Research, 37(4), 393417.

Sağlam, F., (2007). İlköğretim okullarında görev yapan ögrretmenlerin derslerinde bilgi teknolojisi yararlanma öz-yeterlilikleri ve etki algılarının belirlenmesi. Yayınlanmış yüksek lisans tezi, Yeditepe Üniversitesi Sosyal Bilimler Enstitüsü, İstanbul.

Şahin, M. C. ve Arslan Namlı, N. (2019). Öğretmen adaylarının eğitimde teknoloji kullanma tutumlarının incelenmesi. Türkiye Sosyal Araştırmalar Dergisi, 23(1), 95-112.

Yalçınkaya, Y. ve Özkan, H. H. (2014). Ortaöğretim öğretmenlerinin etkileşimli tahta kullanımına yönelik öz yeterlikleri. Mehmet Akif Ersoy Üniversitesi Eğitim Fakültesi Dergisi, 29, 69- 91. 
Yürektürk, F., Coşkun, H. (2020). Türkçe öğretmenlerinin teknoloji kullanımına ve teknoloji destekli türkçe öğretiminin etkililiğine dair görüşleri. Ana Dili Eğitimi Dergisi, 8 (3), 986-1000.

\section{Summary \\ Statement of Problem}

As in all countries in our world, many developments are taking place in the fields of education in our country. It is known that the most comprehensive of these developments is the FATİH project. The main purpose of the FATİH project is to create an environment where teachers and students will use educational technologies effectively and efficiently in their classrooms, and at the same time to make them work more efficiently. In the research conducted by the Van Provincial Directorate of National Education, it is observed that teachers hesitate to use digital technologies due to their old habits. Interactive boards are seen as projection devices and tablets given to students as game consoles. This situation causes waste in every sense. In this direction, this study reveals teachers' attitudes towards the interactive whiteboard. In addition, with the awareness training provided, the knowledge of the teachers is increased and it is ensured that they use ICT more effectively.

\section{Purpose of the Study}

The aim of this study is; İtalya, Slovenya, Romanya and performed with Türkiye's partnership with "Peace With ICT" is the European Union (EU) evaluated the outcomes of the project, employee trainers in public institutions in the country who put their attitudes towards interactive whiteboard is to make a statistical data analysis work.

\section{Method}

Turkey, Italy, Slovenia and Romania in the framework of awareness training is intended to examine the attitudes of the teachers in the interactive board. In this study, a pre-test and post-test experimental design was applied on a single group of experimental designs, which is one of the quantitative research methods. The applied design is on a single group, and the measurements of the subjects regarding the dependent variable are obtained from all participants, including the pre-test before the awareness training and the post-test after. This study was Turkey, Italy, Slovenia and Romania working in the partner organizations identified in 271 countries that constitute educators. 


\section{Findings}

In the research, tests were carried out to determine the attitudes of the trainers working in the partner organizations within the scope of the project towards the interactive whiteboard. Looking at the analysis values, it is seen that the pre-test and post-test average values have changed. Turkey's Education Pre 2.3627, 2.9165 Continuing Education, Pre Romania's Education 2.1238, 3.7249 Continuing Education, Early Childhood Education, Slovenia, 1.7082, 2.1211 Continuing Education, Early Childhood Education Italy 2.4938, and 2.8411 Continuing Education. There is an increase in the averages.

Occupational experience and country variables among the questions used in the scale; "How often do you use computers, laptops or tablets?", "Do you believe in the necessity of instructional technologies for education?" and "How often do you use an interactive whiteboard?" MANOVA analysis was conducted to determine the relationship between them and the variables.

\section{Conclusions and Recommendations}

In order for technology integration to be successful, teachers must be able to use the appropriate technology in their branches. Special trainings are needed for teachers to use the technology suitable for them on a branch basis. Accordingly, after the training given to the participants, differences were detected in the attitudes towards the interactive whiteboard.

When comparing the results of the Pre-test conducted before and the Post-test conducted after the awareness training to reveal the attitudes of trainers working in partner organizations in partner organizations towards the interactive whiteboard, Romania's attitudes towards the Interactive Board have increased positively and this increase amount is higher than in other countries. In addition, Italy, Slovenia and Turkey have also seen a surge in attitudes towards interactive whiteboard. According to the results of the statistical analysis conducted before and after the awareness training, it was seen that the participating countries showed a total improvement of $32.02 \%$. It is concluded that professional experience and Country variables have a meaningful relationship with information technologies and that more training should be given on information technologies in order to have a positive relationship.

Fourgous (2010), Kim and Jung (2010), and Russell (2007) stated that information technologies have a great impact on the development of a country, and by transferring school books to the digital environment, distributing tablet computers to students and educators (Lesardoises, 2012), They stated that a great support would be provided to education by connecting the internet to homes without internet (News Report, 2007) and establishing ICT 
YYÜ Eğitim Fakültesi Dergisi (YYU Journal of Education Faculty), 2021; 18(1)494-521,http://efdergi.yyu.edu.tr,

classes (MEB, 2012a). The awareness training given in line with this study encouraged the participants to use digital technologies.

In the study conducted by Yücekaya and Akgün (2015) and Özcan and Polat (2014), it was stated that interactive boards increased the motivation of students and had a permanent effect on learning the subjects. It has been observed that when teachers do not improve themselves and use the interactive board effectively in their classrooms, they do not contribute much to the development of students (Al-Qirim (2011)). In order for teachers to use ICT effectively in their lessons, such awareness training or in-service training should be given.

It is thought that the project exemplified within the scope of the study and the dissemination of projects aimed at increasing the usage capacity of similar technological devices will affect the quality of education and student development positively. 